\title{
APPROVING OR MORTIFYING ONLINE AND CITIZEN JOURNALISM BY MAINSTREAM JOURNALISTS: A CASE FOR CREDIBILITY TRANSFER HYPOTHESIS
}

\author{
Peter Chierike Ikegbunam \\ Communication Scholar \\ p.ikegbunam@yahoo.com \\ Phone: 07036280407 \\ Fabian Ikechukwu Agudosy \\ Department of mass communication \\ Chukwuemeke Odumegwu Ojukwu \\ University Igbariam Campus \\ fabian_agudosy@yahoo.com \\ Phone: 08036860238
}

\begin{abstract}
The relationship between online and mainstream journalism, over the years, has been critically reviewed negatively by practising journalists. Among the mainstream practising journalists, online and citizen journalism are peddlers of uncensored and junk contents. This study, though a review of reported events, looked at the relationship between mainstream and online contents. The purpose of the study is to verify whether the mainstream media mortify or certify online journalism. This study adopted the critical discourse analysis in reviewing what was reported in both mainstream and online media. The study, which made a case for the credibility transfer hypothesis, revealed that rather than spread junk contents, the online press helps the mainstream media in explaining to the world what is happening around them. Drawing from the outcome of the study, it was found that the online media and citizen journalists break the news while the mainstream media follow suit with few additional contents that give more insight into the stories of the moment. The study concluded that rather than mortify the contents of online media, the mainstream media transfer credibility to it by drawing their publications from the online materials. The study, therefore dismissed allegations from mainstream journalists against online and citizen journalists that they spread junks. It was recommended that the mainstream media journalists and media experts should desist from making some derogatory remarks about online media contents but rather, incorporate online and citizen journalisms' contents in their mainstream reports for adequate and on-the-event coverage of issues
\end{abstract}

Keywords: Credibility transfer hypothesis, online media, mainstream media, Mortifying, Approving, Junk

\section{INTRODUCTION}

A cursory look at media practitioners' positioning of online media reports among mainstream media journalists sets the mind in motion for specific probing questions concerning the relationship between the two. In the eye of many mainstream journalists and reporters, every piece of information from the online versions is seen with a certain level of credibility and acceptability. Some call it junk journalism and all sorts of names to ensure that they ridicule the contents of online press. At this point, it becomes ultimately fascinating to probe the contribution of online press in development of media in this modern age? It is expected that the advent of the online media networking system should encourage and strengthen the 
means of information dissemination by reducing the time-cost of the passage of information from one end to another. The view above negates the view expressed in the work of Anderson (2010) who noted that the advent of new media technology had a substantial impact on media and its audience for the past decade.

Considering the position held in Anderson above, new media impact on media development and evolution should be encouraged rather than discouraged as can be found in the castigating views held among the mainstream journalists in the wake of the new media information dissemination to the public. The view was fundamentally that the operators in online media networking sites are not professionals and therefore are not ready and cannot produce a content professional enough to be credible, hence the name"Junk journalism." This view was justified in the words of Reese (2016) who argues that manipulation in the online media will affect the mainstream media to a large extent. The authors further, confirmed that online media had become an indispensable means of passing information around the world and the greatest disseminator of current information from one end to another.

Unfortunately, there seems to be a kind of antagonistic relationship existing between the online media operators and the mainstream media journalists, this makes them see online media contents with contempt. Despite this critic against online media, it perseveres. The pervasiveness of the online media in society has led to much speculation about its consequences for journalism and, more generally, the socio-political engagement of citizens. While there have been some dramatic changes for journalists and professional news organizations as a result of technological developments, it is the discussion around participation of the non-professional in the editorial process that has moved to the fore. The non-professional operators in the system are the base for the credibility issue that this papers set to address. In this light, Deuze, Bruns and Neuberger (2007, p. 323) contend that "digital and networked journalism in whatever shape or form must be seen as a praxis that is not exclusively tied to salaried work or professional institutions anymore." The contention above points at the fact that online media practice has made journalism profession less professional with little or no pay at times yet disseminates information. To Bakker and Paterson (2010), the crises between online media and the professional media handlers are anchored on the superiority of one over another which media scholar had neither acknowledged nor dismissed. Carefully considered, all mainstream professional practitioners subscribe to online media network to get one item of information of the other.

Proponents of the credibility question on the online media contents argue that the sources are not attributed, and the facts not accurately stated (Nwabueze and Ikegbunam, 2015, Asemah, Olumuji and Edegoh, 2013, Agbanu, 2013). These views also mount severe pressure and suspicion on the contents of online media indirectly, pre-empting the criticism that the mainstream journalists level against online journalism. Research evidence has shown that, the online media information came faster than those of the mainstream media (Nwabueze and Ikegbunam, 2015) and sometimes formed the base of mainstream media reports. This is the question that begs for an answer. Why should the traditional journalists after borrowing sources and citing online media contents, claim that they are junk in the eye of experts? It is against this background that this study sets to probe the position of the mainstream journalists: are they mortifying or approving online journalism based on their actions and words concerning contents. 


\section{STATEMENT OF THE PROBLEM}

Media experts and mainstream journalists have been castigating online media contents for lack of quality, negligence of journalism ethics (Nwabueze and Ikegbunam, 2017), poor gatekeeping function, lack of accuracy, user-generated contents, all man's affair and inadequate attribution to sources (Nwabueze and Ikegbunam 2015; Agbanu, 2014). All these cast terrible images on the contents of online media outlets, making them look inferior and unbelievable before the people. To this end, a reasonable number of people today never accept that what they see or read from online is accurate or valid until the mainstream journalists report the content, many a time with the online media that carried the story earlier cited.

Again, many researchers have examined the credibility of the sources of online media outlets, and the results always indicate that the advent of online media has drastically dragged the journalism profession to ethical criticism. Unfortunately, little or no attention has been paid to the fact that mainstream media sometimes cite the online media which they always criticize for lack of accuracy, negligence of ethics and weak gate-keeping role. The position of this paper therefore is to establish the realities on the antagonism between online and mainstream media journalists.

\section{RESEARCH OBJECTIVES}

The mainstay of this study is establishing the antagonistic relationship between the mainstream and online media practitioners, and the measurable research objectives are:

To ascertain whether mainstream media reporters reference online media contents in their reports on the select activities understudy.

$>$ To determine the level of referencing online materials by mainstream media reporters on select events understudy.

$>$ To verify the level of accuracy of the information in the mainstream and online media reports on the select events under investigation.

\section{THE SCOPE AND LIMITATION OF THE STUDY}

This study is focused on selected events in the country that attracted media reactions in both mainstream and online media reports. The activities under investigation were the $13^{\text {th }}$ April 2018 episode in the red chambers where the mace was stolen at the floor of the senate; the operation python dance II in southeastern Nigeria as announced in August against September 2018, the Senator Dino Malaye result scandal of March, 2017, and the President Buhari's comment on the lazy Nigerian youths of April, 2018.This study examined the contents of these select events. It pays attention to details on the relationship between reports from select online media outlets and what their mainstream counterparts issue on same activities.

Any other contents of the online media reports done on other issues other than the ones above were not considered. The consideration was based on the contents of the above selected online media against their mainstream counterparts Daily Sun, Vanguard and Guardian newspapers. Other newspapers in the country were not covered in the study. However, the implication of the choice of the above online and mainstream media outlets is that they may not be able to represent the two groups of media structures under review and that recommendations and conclusions were based on their contents specifically on the select issues under study. Another study in the same direction may supply different conclusions and recommendations if taken out of these areas under consideration. These media organizations under study were selected for this study because of their wide readership and circulation in 
the country. Moreover, the researchers' discretion also informs the choice of the media outlets under study.

\section{SIGNIFICANCE OF THE STUDY}

This study examines the contents of mainstream and online media on the selected events above that took place in the country to revealing whether the mainstream journalists approve or mortify online media contents given the kinds of criticism that online media get from them over the accuracy, gate-keeping and all other professional journalistic requirements. Being a new area in communication studies, the study revealed the antagonistic relationship between the two categories of journalism. It exposes the hypocritical nature of mainstream journalists' mere claim of lack of credibility on the part of online journalism by showing that their contents tally in some cases.

The study also introduced the concept of credibility transfer hypothesis into media and communication studies. Based on the premise of this hypothesis, the study reveals that integration of the two categories of journalism is a perfect means of making a breakthrough in the satisfaction of the necessary information need of the fast-growing society in the $21^{\text {st }}$ century. The study, therefore, is an attempt at putting to a stop, the height of negligence of online contents among the people simply because of mere mainstream journalists' public condemnation of its contents and subtle tapping from the wealth of its globalization tendency for their survival.

Generally, this study benefits all media scholars in the sense that it has introduced a new concept "credibility transfer hypothesis" in journalism study. The study has also exposed the hypocrisy of mainstream media reporters against their online counterparts. At the same time, the paper has settled the age-long antagonism and provided a template for understanding the nexus between online and mainstream press. On this background, the study is pertinent to both mainstream and online reporters because it has provided a link between what is published in online and mainstream press. Incorporating one another's contents and materials which this study advocates will go a long way in improving the qualities of contents and timeliness in media practice. Upholding the contents and materials of one another in the practice will help restore the credibility and trust of the public which is gradually going sour against journalism profession.

\section{EMPIRICAL LITERATURE REVIEW}

The researcher in this study examined the relationship between these two categories of journalism using available empirical and theoretical literature. Earlier media scholars have attempted an exploration into the relationship between mainstream and online media in different ways. Kwak, Kim, and Zimmerman, (2010) in their study, confirmed that media audience perceived user-generated content as equally reliable and likeable as mainstream content. They further stated that although the previous persuasion literature has tended to employ expertise and trustworthiness as two main sub-dimensions of source credibility.

Similarly, Kellner, (2012) affirmed that the relationship between the mainstream and the internet media has been very much like that of the cat and dog when credibility is concerned. Because of that the author concluded that the persevering nature of internet media in sending messages to many people at the shortest possible time made it more thriving in the society in an era of information consciousness (O'Keefe, 2002), their results indicate that they are two distinct concepts. The results showed that people who think the source is an expert might not 
always believe the source to be trustworthy. This is because expertise and trustworthiness reflect two different elements that contribute to source judgments among the audience.

Using the Arab Uprisings that began in 2010, Bahja, (2013) demonstrates how citizen journalists were able to utilize novel forms of communication, ranging from blogs to social media, to ensure that their voices are not silenced even in the face of severe government clampdown on media. The author concluded that these voices from the internet enabled media platforms become a vital source of information for the mainstream media around the world. For the mainstream media, citizen journalists offer local "scoops" from the ground that would otherwise be inaccessible and, for citizen journalists; the mainstream media offer a platform to share their stories with the world. The import of this is that there is the need for collaboration for international best practices and not antagonism with each other. Nah and Chung, (2016) reveals that online media can coexist, compete, collaborate, coordinate, and compromise with professional journalism through communicative action, such as mutual understanding, reason-based discussion, and consensus building for enhancing international best practices in journalism profession.

Unfortunately, internet media cannot be deleted from the media space, instead incorporating them may be the best for journalism practice. The above view was supported by the idea expressed in Kellner, (2012) where he stated that the internet makes accessible more information available to a more significant number of people, more efficiently, and from a more extensive array of sources than any instrument of information and communication in history. This fact underscores the importance and indispensability of the internet media in the media studies and communication discipline. Nwabueze and Ikegbunam, (2015) after a crossexamination of specific issues covered in the mainstream and social media landscape concluded that the internet blog stories are not that bad as the mainstream journalists and media experts are assuming them.

In another study, Višňovský and Radošinská (2017) explored the theoretical issues of online journalism and discussed the specific forms of internet-delivered journalistic production and professional requirements placed on journalists who specialise in online news-making. The requirements under review were based on the current development tendencies of digital communication forms. One of the key issues discussed by the researchers in this study is that of credibility. The study examined how consumers measure values among, elite media institutions, with their gatekeepers, resources, and professional codes and training, on one hand, and, the bloggers; wiki-ists and e-mailers, with their editorial independence, collaborative structures, and merit-based popularity on the other hand (Russell, 2013). The study which adopted the critical discourse analysis method concluded that contemporary journalism needs to implement innovations very quickly. It also suggests that online versions of the press and mobile applications have to closely watch all emerging trends in digital communication in order to maintain their competitiveness.

Noor, (2017) examined how journalists perceive the impact of citizen journalism on mainstream journalism and their work. The study also investigated whether citizen journalism pose threats/challenges to the mainstream media. The study which used the survey of journalists from Kashmir found that citizen journalism serve as both alternative news source to the people and exposes mainstream journalist to news events that are inaccessible to them. It was also found that the online media does not pose any challenge to the mainstream media. This was collaborated by the Karlsson and Clerwall, (2019) who argue that a remedy to the 
decreasing trust in news may not be blamed on the changing of norms in journalism brought by online media, but rather on how the already established norms and values of the journalistic professions are performed.

Yamamoto, and Nah, (2018) found that as structural pluralism is negatively related to local newspaper credibility, conservative ideology, newspaper use, social trust, and political trust are significantly related to local newspaper credibility. The basic issue here is the credibility of the source of information which is dependent on how the source presented itself to the audience. Luo, \& Harrison, (2019) study concluded that the online media does not only act collectively to influence and contribute to the content of the traditional media but also influence policies that the government considers, and in so doing, changing the nature of journalism and public sphere in china.

Of all these studies, the researchers are interested in the relationship between the two fourth and the fifth estate of the realm. They were more interested in the link shared in stock by the contents. This study is different because it sets to examine the materials from the view of the crisis existing between them over the credibility question. Against this background, the researchers considered the contents from the transfer of credibility position. They focused attention to the believability of the sources among the audience. Because the work was premised on the credibility transfer hypothesis, the researcher dwells on establishing how and when credibility is transferred from a source of information to another in journalism practice.

\section{SOURCE CREDIBILITY THEORY}

The source credibility theory as propounded by Hovland, Janis and Kelly (1963) stated that people or receivers are more likely to be persuaded when the source presents itself as credible. Furthermore, Hovland (1963) and Weiss (1974) later studied the influence of sources in persuasion. The study was done by comparing reliable and non-credible sources using the same persuasive message to test if the sources seen as reliable could influence opinions to change in the message receivers more than the non-credible source. The study confirmed the assumption that trustworthy sources tend to create the desired impact on the audience. The credibility of the media source has been studied in various disciplines.

Eisend (2004) studied credibility of the source in marketing, Arpan, (2002) in crisis management, Clow, James \& Stanley, (2008) in advertising, and Bates, Romina, Ahmed \& Hopson, (2006) examined the credibility of the sources in health information. The reliability of the sources has also been used in measuring the influence of source credibility in advertising on consumer attitudes in the service industry. Clow, James and Stanley (2008) used the dimensions of expertise, trustworthiness, attractiveness, similarity and liking to measure source credibility. Bates, Romina, Ahmed, and Hopson(2006) has been testing the credibility of the source to measure the quality of health information on the website by using the dimensions of reliability of information; informed consent; legibility of the data; and completeness of the information. Drawing from this postulation, the acceptance of data from the online media is a matter of understanding sustained by packaging, which is dependent on the media outlet.

\section{Credibility Transfer Hypothesis}

Given the nature of this research, the researchers came up with the "Credibility Transfer Hypothesis $(\mathrm{CTH})$ ". This hypothesis was brought forward to help explain the antagonism of criticism thrilling the relationship between online and mainstream media reports among 
professionals. In media practice, what every media outlet struggle to get among its audience is credibility. It sustains the media outlet, and its lack spells doom for any journalist and organization. The reason is that the journalism industry survives on adverts and, no corporate organization can give out their products' advert to a non-credible organization. This was captured in Saad, (2016); Barthel, (2016) studies which reveal that loss of public confidence in any media industry will result in declines in circulation, readership and advertising revenues. The above scholarly findings were made more clear in Yamamoto and Nah, (2018) study which argues that loss of credibility undermines the role of any media outfit to inform the people on events around them.

Credibility transfer, as the name implies means the act of giving the impression that a news source is reliable. The authors of this paper define credibility transfer as the act of making a source of information reliable by lifting materials from the source and citing the source. The position of the credibility transfer hypothesis is that credibility, trust, and reliability can be transferred from one media organization to the other. The authors opine that once a source accepted by the public as reliable lifts materials from another source suspected to be unreliable and cite same, credibility is transferred. In Nigeria, for instance, readers have trust in different newspapers. Their trust sustains their patronage of the news source.

The authors in this study are of the view that the mainstream newspapers transfer credibility to any online media outlet when they cite them in their stories. Based on this ground, this hypothesis, states that once a media organization accepted among the readers to be credible cite(s) other organization that is less accepted among the readers, the former has transferred its credibility to the latter. It is the position of the proponent of this hypothesis that any organization that cite(s) a less reliable media outlet cannot adjudge the media cited as not trustworthy and inaccurate; neither can they accuse them of eroding the ethical precepts of journalism.

On this ground, should the data from this study show that the mainstream media after criticizing the online media outlets go undercover to tap information from them and cite them, the researchers will conclude that mainstream journalists rather than mortifying online media, are approving it. This is because, by citing Premium Times in national dailies, the readers of such national dailies who accept their contents to be reliable will equally begin to see Premium Times as a reliable media outlet in future reports.

The hypothesis is an off-shoot of the source credibility theory which proposed that the audience of any media content tend to see the contents as credible if the supplier of the information is seen as reliable. Be that as it may, there are two most commonly visible elements which positively influence source credibility and they are: perceived expertise and trustworthiness of the source. Commenting on this, Cornan, Hess and Justus (2006), submitted that there are three key dimensions of credibility which are trustworthiness, competence, and goodwill. These three dimensions are not empirical realities but perceptions that can be created, managed over time, and cultivated in the audience. This requires a coordinated approach to message design, delivery, and most importantly, adaptation to the given audience and current media situation (Umeogu, 2012). 


\section{METHOD}

This paper adopts the textual analysis research method in evaluating the contents of mainstream and online media coverage of issues concerning the selected events in Nigeria that constitutes the study scope. The choice of textual analysis was basically because it lends the researcher the opportunity to examine both the online and mainstream media contents with a view to finding if there is an element of resemblance on one side and citation of the online source in the mainstream media on the other side. Textual analysis is concerned with the gathering and critical evaluation of media messages from selected media outfits.

The research uses McKees (2003) post-structuralist view that "educated guesses can be made about the most likely interpretations of texts based on 'given cultural contexts." Premium Times, Shahara Reporters, and Linda Ikeji blog represent the online media while Daily Sun, Vanguard and Guardian newspapers represent the mainstream media in the study. The choice of these newspapers and the online media organizations was informed by their wide readership in Nigeria, accessibility and the researchers' discretion.

Any online news story with pictures, by-line of the reporter, the source of the story, the names of the actors or preys in the story are classified as accurate in this study. On the other hand, any story found in the mainstream media citing any of the three online media outlets understudy is classified as "cited or acknowledged" while those without citation were classified as lifted without citation if they report the same event after the online media must have aired the publication. The level of referencing was measured by the percentage of what is lifted and what is cited by the mainstream media.

The population of the study was drawn from the days of the months upon which the events under investigation took place. The population covers all contents covered by any of the select media outfits within the specific month when the event took place. Thus there are a total of four months in the study period which covered from March, 2017 when the Dino Malaye's Result scandal sprang up in the media; the operation python dance II in southeastern Nigeria of September 2017; the stolen mace at the floor of the senate of April 2018 and the President Buhari's comment on the lazy Nigerian youths of April, 2018.

This means that a total of 121 news editions from each event are covered making a total of 726 editions for the six media outlets covered in the study. Drawing from the fact that the media organizations do not report a particular event every day of the week, the researchers adopted the purposive sampling technique in analyzing news contents covered by any of the six media outfits on any of the four events under investigation. In doing that a total of 326 news stories on the selected events were discovered to have been reported in the six media outfits selected for the study.

\section{DATA PRESENTATION AND ANALYSIS}

This study presented all data collected in the qualitative and descriptive analysis all against the research question that calls for it. From the information obtained in the field, the researcher found that there are a total of 326 stories published by the selected online and mainstream media under study. From these 326 stories 205 were from online media while 121 other stories were from the three selected newspapers concerning the salient issues selected for the study. 
Volume 1 Number 1 Maiden Issue

A breakdown of these stories shows that the Sahara Reporters news items were on the lead with a total of 75 stories followed by Linda Ikeji blog which carried 67 items while Premium Times reported a total of 63 items. Of all the issues under reporting, the Operation Python Dance II was the most celebrated issue in social media while that of the Senator Dino Malaye's result scandal was more visible in the mainstream counterpart. The reason for this may not be too far from the fact that it happened earlier than the other two events which took place in 2018. On the mainstream media reports on the issues under study, Daily un was on the lead with a total of 47 items followed by Vanguard newspaper with 39 items while Guardian newspapers had a total of 35 items

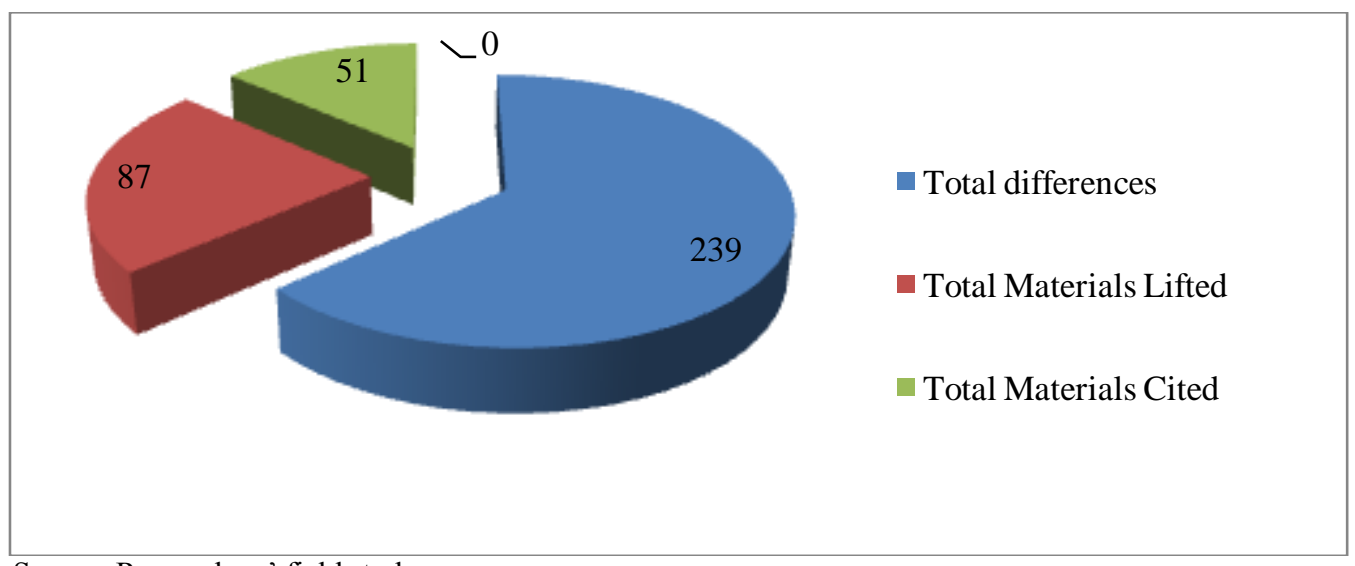

Source: Researchers' field study

The figure shows the differences and similarities in news story contents between mainstream and online media. The figure revealed that there was a total of 326 news stories on Senator Dino Malaye's result scandal, Buhari's speech on the lazy Nigerian youths, the Operation Python dance II and the stolen mace at the floor of the senate chambers. Of these news stories, mainstream media published a total of 121 among which a total of $87(71.9 \%)$ of the items/materials were lifted from the online media. Among the 87 items lifted, 51 or $62.9 \%$ of all the items lifted from online media were cited by the mainstream media. This implies that the online media serve as source of information for the mainstream media. In the views of these researchers, citing online sources as the originators of news materials as revealed in this figure, means 'transfer of credibility' to the online media channels. 
NNAMDI AZIKIWE UNIVERSITY Journal of COMUUNICATTON AND MEDLA STUDIES

Volume 1 Number 1 Maiden Issue

Table 1: Showing number of stories per event understudy in online media

\begin{tabular}{|c|c|c|c|c|c|}
\hline Variables & $\begin{array}{l}\text { SaharaReporter } \\
S\end{array}$ & $\begin{array}{l}\text { Premium } \\
\text { times }\end{array}$ & Lindaikeji & Frequency & $\%$ \\
\hline $\begin{array}{l}\text { Python } \\
\text { Dance II }\end{array}$ & 30 & 24 & 21 & 74 & 36.0 \\
\hline $\begin{array}{l}\text { SDM Result } \\
\text { issue }\end{array}$ & 17 & 11 & 14 & 42 & 20.4 \\
\hline $\begin{array}{l}\text { Senate } \\
\text { stolen mace }\end{array}$ & 21 & 18 & 12 & 51 & 24.8 \\
\hline $\begin{array}{l}\text { Lazy } \\
\text { Nigeria } \\
\text { youths }\end{array}$ & 7 & 10 & 21 & 38 & 18.5 \\
\hline Total & 75 & 63 & 67 & 205 & 100 \\
\hline
\end{tabular}

Source: Researchers' field data, 2020

This table shows the individual online media news stories on the four selected events under investigation. The data in the table implies that Operation Python Dance II and the stolen mace at the floor of the senate were given more attention in the online media. The table revealed that the Senator Dino Malaye's result scandal controlled 51 news stories of the 205 stories observed and studied in the online media. This table shows the power of the online media in enhancing democracy in Nigeria. Considering the number of stories published by the online media, the era of limited space in the traditional media is gradually getting under control.

Table 2: Showing number of stories per event understudy in mainstream media

\begin{tabular}{|c|c|c|c|c|c|c|}
\hline Variabl & & Daily Sun & Vanguard & Guardian & Frequency & $\%$ \\
\hline $\begin{array}{l}\text { Python } \\
\text { II }\end{array}$ & Dance & 13 & 9 & 11 & 33 & 27.2 \\
\hline $\begin{array}{l}\text { SDM } \\
\text { issue }\end{array}$ & Result & 12 & 15 & 14 & 41 & 33.8 \\
\hline $\begin{array}{l}\text { Senate } \\
\text { mace }\end{array}$ & stolen & 12 & 9 & 5 & 26 & 21.4 \\
\hline $\begin{array}{l}\text { Lazy } \\
\text { youths }\end{array}$ & Nigeria & 10 & 6 & 5 & 21 & 17.3 \\
\hline Total & & 47 & 39 & 35 & 121 & 100 \\
\hline
\end{tabular}

This table shows the individual mainstream media news stories on the four selected events under investigation. The implication of this data is that the mainstream media is more interested in covering Senator Dino Malaye's certificate scandal than severe issues of national concern such as the Operation Python Dance II in the southeastern Nigeria and the stolen Mace at the floor of the Nigerian senate. The hypocrisy of the mainstream media and the shrinking civil space was brought to the fore in the above data, especially considering the manner in which the press is being rough handled by successive administration in Nigeria. 
Volume 1 Number 1 Maiden Issue

\section{DISCUSSION OF FINDINGS}

The first research objective considered whether mainstream media reporters cite online media contents in their reports. On this note, this study revealed that the mainstream media diligently draw their contents from the online and citizens journalism materials and at times cite or abscond from citing them as well. The implication of this finding is considered impactful in that rather than ridicule journalism profession, online and citizen journalists have positively influenced the development of journalism by encouraging prompt and timely dissemination of messages to the public. It means that the online media augment the mainstream media contents by appearing faster and serving as the first source of breaking news. This finding is in tandem with the view expressed in Ján and Jana, (2017) where the authors agree that the online and internet media have made their mark in improving on the development of journalism. The finding also corroborates the views of Eldridge II, (2017, p. 45) who holds that journalists' use of social media, interactive live blogs or the work of more activist oriented interloper media like WikiLeaks; the work of new digital journalists is increasingly commonplace and becoming very visible.

Considering the position of the researchers on the credibility transfer hypothesis, this study had shown that the mainstream media criticism of the online journalism is unwarranted since they lift their sources to augment their news stories. Mainstream media do not only cite the online media as the source of their information but "copy" them even exactly in their own reports. A look at the number of stories in the entire events covered by the two media platforms and the synchronization between the online and the mainstream contents justifies this finding. On September 7, 2017, Premium Times break the news of the operation python dance II. With a headline: "Breaking: Nigerian Army to begin exercise Python Dance II in South-East"

With this report the Premium Times has taken the lead on the operation python dance as all other media channels continue to flow this report and subsequently make references to their reports based on interviews they revealed to the public. The following day, the report went awash in different mainstream media with different headlines. Similarly, Premium Times news published on $5^{\text {th }}$ June on Senator Dino Malaye's result scandal found its way in the mainstream media three days later but the source was never cited by Vanguard. (See vanguard news of June 8. Video: Declaration of result for the recall of Dino Malaye).

However, this relationship came at the expense of the once highly valued media pillar of "Verification" or "Objectivity". The coverage of the selected events that took place in the country demonstrated how the mainstream media's reliance on citizen journalism came at the expense of accurate and objective reporting. Should the online media be accused of lack of accuracy and objective investigations of facts, what then will be said of these mainstream media outfits which lift materials from the online contents? This is to say, that if the mainstream media after accusing the online media as being incredible, tap from their content, then all will be guilty of unverified dissemination of information to the public. It would be recalled that the reliance on citizen journalism increasingly threatens the credibility of the mainstream media and in turn transfers same to the online media copied. However, by relying on the contents of the online media for information among the mainstream media, the much desired credibility which was alleged to be lacking among the online media have been bestowed on them, and thus makes it believable among the audience. 
Volume 1 Number 1 Maiden Issue

On the second research objective that considered the level of online media contents cited by the mainstream media, this study revealed that there was a high level of citations of online news media in the mainstream stories. Of the 326 news stories on the four events under investigation, mainstream news media covered a total of 121 from where 87 (71.9\%) were lifted from the online media. From these 87 news stories lifted, 51 or $62.9 \%$ were cited (see figure one). Looking at these data, $71.9 \%$ and $62.9 \%$ are all above $50 \%$ which can best be regarded as pass mark. This means that the mainstream media have high level of acknowledging materials that they lifted from the online media. This finding disagrees with Ude-Akpeh And Ukwella, (2017) which condemns online media contents on the basis of the allegations of disseminating unprofessional contents.

Drawing from the proposition of the credibility transfer hypothesis, for citing online media as originators of contents, the mainstream media have transferred credibility to them. It is of no use going behind the backdoor to call them unqualified, uncensored and quacks. This finding also is linked to the source credibility theory which maintains that sources of news stories are perceived to be reliable if they present their contents in manners that convince the readers to accept them as reliable (Clow, James \& Stanley, 2008). Relying on the data from the field, this study revealed that the online media have demonstrated a high sense of responsibility for their news stories. For instance, on $24^{\text {th }}$ September, 2017, SahararReporters came up with a story on Operation Python Dance II with the headline: 'Our Lives under Python Dance II: South-East Residents Speak'. This story captured the position of some prominent men in southeastern Nigeria on the influence of the military operation mounted in the zone. The next day, the mainstream media resumed to publish views of the people on the operation and made some references to SaharaReporters on the issue. SaharaReporters $19^{\text {th }}$ April once again opened the space for the reports on the Mace scandal in Nigeria when the suspects were named with a headline: 'Stolen Senate Mace: Names of Suspected Thugs Released'.

The above was quickly followed by Premium Times on $20^{\text {th }}$ April with a caption: Senate, Thugs and the Mace: Understanding Parliamentary Misconduct, By Jibrin Ibrahim. This was in tandem with Miller (2010) who reported that online media journalists can be active in the creation of news and very fast in reporting events more quickly and reach a larger audience than traditional media. The high sense of responsibility in attribution to sources and provision of by-lines make the online media more credible in their reports. This may account for the reason mainstream media was found lifting and citing them. The finding further brought the all-round drastically improving importance of online news sources to the survival of journalism in this fast growing world (Zerfass, Verhoeven, Moreno, Tench, and Verčič, 2016).

Every other report from the mainstream media followed suit but were emanating from these reports blown above in the online media. This finding shows the complimentary role of the online media to the mainstream. As for the credibility of the contents, the implication of using the online source is that the mainstream media have acknowledged that online media contents are credible. Then, why the criticism of the online media contents by media professionals? Considering the impact of the online media to mainstream media, former head of global news for the BBC Richard Sambrook said "people were participating in our coverage in a way we had never seen before (Sambrook, 2005). By the next day, our main evening TV newscast began with a package edited entirely from video sent in by viewers." This statement means that the people in the streets hunt for news and send same to the various online media for publication. 
Unfortunately, the people may not have access to the mainstream media and therefore left with the only option to send to the online media who now break the jinx for the mainstream media to follow. It cannot be out of place to state that some of the mainstream media organizations have User Generated Content (UGC) editors whose duties are to monitor what comes in from the users on daily bases for further investigation of content before use. Many discussions of user-generated content have been along the lines of "Do people find usergenerated content credible?" or "Are bloggers more powerful and persuasive than traditional media?" (Johnson \& Kaye, 2004; Dearstyne, 2005; Porter, Trammell, Chung, \& Kim, 2007). Previous studies have shown that the communicator's occupation-expert vs. non-expert determines source evaluations (O'Keefe, 2002). The views above by these scholars are now questionable in the light of the findings of this study.

Moreover, expert and non-expert factor never played in from the research findings because the experts now copy and reference the non-experts. The finding justifies the glaring impact of the internet media on the mainstream media of communication and therefore agrees with Ekeli and Enobakhare, (2013) who argued that any manipulation in the internet media is most likely to influence the originality and as well the credibility of the mainstream contents.

On the level of accuracy of the information in the mainstream and online media reports, the researchers found that both the mainstream and online media share almost the same level of accuracy because of the fact that they tread on the same coast for their information. It was found that in some cases, the mainstream media gather their information from the online and do no further investigation to get more details on the facts reported for public consumption. However, it is pertinent to state that some of their reports, the mainstream media add some substances to the news already covered in the online media. This study found that the online media outfits which survive on the clicks have adopted the professional style of not only attributions to sources, by supplying of all necessary details for verifications of the news stories.

For instance, Premium Times on $5^{\text {th }}$ June came up on Dino Malaye with a headline: Bribery Tape: Dino Melaye, Smart Adeyemi tango on TV. The story was written by Hassan Adebayo. The story detailed the incidence on Dino Malaye's result scandal from a thorough investigative angle exposing the nutty gritty of the case. The story provided all the elements of good news reports and presented itself to be reliable.

Similarly, the Vanguard newspaper published a story on operation python dance II with a headline: 'Operation Python Dance II: One week after'. This story was published on September 23 as a news comment with a bye-line: Vincent Ujumadu and Anayo Okoli. Inside the story, the details of the comments made by the Army Chiefs in-charge of different divisions selected for the operation were the same with the one contained in Premium Times story published on $20^{\text {th }}$ day of the same month and that of Sahara Reporters published on the $21^{\text {st }}$ day of the month and Lindaikeji published on $22^{\text {nd }}$ day of the month. On the $13^{\text {th }}$ day of September, the position of the Abia State Governor, Okezie Ikpeazu on the curfew was made known to the public in a media chat and the comment he made was captured by all the media channels the same way. The curfew statement reads: 
Volume 1 Number 1 Maiden Issue

\begin{abstract}
Abia state has for the past few days been the focus of security searchlight occasioned by the reported skirmish between some groups in the state, especially Indigenous People of Biafra (IPOB) with men of the Nigerian Army. Government notes and has observed the frenzy of activities of members of IPOB within Afara-Umuahia, the ancestral home of the leader of IPOB for some months now. Government is equally aware of the recent proclamation by the Nigerian the Nigerian Army of Operation Python Dance II within the south-East geopolitical region of Nigeria.
\end{abstract}

This statement was earlier published in the night of $12^{\text {th }}$ September 2017 in all online media including facebook in this very way. The implication of this is that the online media equally attend media chats and tender their reports on issues covered. The only difference with the reports is their headlines and styles of writing which usually differs even among mainstream media organizations. The above finding disagrees with the position held in Mandlios, (2013) that stories from the internet media are often characterized by made-up contents published to gain clicks. In summary, the finding shows as can be found in Nwabueze and Ikegbunam (2015) that there are no much differences between the contents of internet media and the mainstream media stories especially, when they report the same event.

Further investigations revealed that as the mainstream media cite online media contents on some issues, the online media also cite the mainstream media on certain issues depending on which media is basically grounded on the event under investigation. However, it could be recalled that some of the stories from the online media examined in this study have bye-lines showing the names of the writers as in mainstream media. This finding is in line with the provision of the source credibility theory of the media which proposes that a story attracts and holds attention of the public and is therefore, considered to be credible once the source of the story presents itself as credible (Lasica, 2003; Asemah, 2011; Murphy and Auter, 2012).

With the presence of by-line and attribution to sources, the online media in this study has vindicated itself from lacking credibility. So rather than ridicule journalism practice, online media outfits have changed the narrative by making news available from all corners of the world. This finding is in line with the position held in Bahja, (2013) who stated that unprecedented rise of citizen journalism had impacted significantly on the mainstream media in the last few years. Among the online media examined, it was found that not even all the public comments or contributions made by the readers are reflected on air. This is some kind of gate-keeping which puts the online media editor(s) on the obligation to check what comes up and what goes down.

\title{
CONCLUSION
}

From the findings made above, this study concluded that rather than mortifying the mainstream media, journalists approve the online media and citizen journalism and as well, transfer the much desired credibility that was alleged to be lacking in them through borrowing or lifting contents from them either with or without being acknowledged as found in them. This study draws from Višňovský and Radošinská (2017) who state that the key to economic success and popularity regardless of which kind of media or distribution channels always lies in understanding the audiences, their behavioural patterns, expectations and needs to dismiss the criticism of online media by the mainstream media practitioners and experts.

\section{RECOMMENDATIONS}

From the findings and conclusion of the study, the researcher recommended that:

The mainstream media journalists and media experts should desist from making some derogatory remarks about the online media 
contents but rather incorporate them in their reports for effective and on-the-event coverage of issues.

$>$ The mainstream media reporters should be objective enough to cite the online media channel when their contents are lifted.

$>$ The online media should strive the more to attribute to sources, provide accurate details and by-lines to earn the credibility that has been bestowed on them by the mainstream media.

\section{REFERENCES}

Agbanu, V. N. (2013). Mass communication introduction, techniques, issues. Enugu: Rhyce Kerex Publishers.

Agbanu, V. N. (2014). Propaganda, mass media and public opinion.A discourse on the battle for people's mind. Enugu: Rhyce Kerex Publishers.

Anderson, C. W.(2010). Journalistic Networks and the diffusion of local news: The brief, Happy News life of the 'Francisville Four' political communication 27(3) pp. 289-309. Doi: $10.1080 / 10584609.2010 .496710$

Asemah , E. S., Olumuji, E. \& Edegoh, L.O. (2013). Citizen journalism and credibility: A study of Sahara reporters.com. ANSU, Journal of Arts and Social Sciences. (2) 1-13.

Asemah, E.S. (2011). Selected mass media themes. Jos: Martol Press.

Bahja, F. (2013).Citizen Journalism and The Mainstream Media: An Analysis Of 85 New York Times Articles On The Syrian Civil war.

Bakker, T. \& Paterson, C. (2010). The new frontiers of journalism: Citizen participation in the United Kingdom and the Netherlands, (pp. 183-199). In K. Brants \&K. Voltmer (eds.). Political Communicationin Postmodern DemocracyChallenging the Primacy of Politics.

Barthel, M. (2016). Newspapers: Fact sheet. Pew research center journalism \&media.Retrieved from http://www.journalism.org/2016/06/15/newspapers-fact-sheet/

Bates, B. R., Romina, S., Ahmed, R. \& Hopson, D. (2006).The effect of source credibility on consumers' perception of the quality of health information on the Internet. Medical Information and the Internet in Medicine, 31(1), 45-52.

Clow, K. E, James, K. E.,\& Stanley, S. (2008). Does source credibility affect how credit cards are marketed to college students. The MarketingManagement Journal, 18(2), 168-178.

Cornan, S., Hess, A., \& Justus, Z. (2006). Credibility in the global war in terrorism: Strategic principles and research agenda. Consortium for strategic communication, Phoenix Metropolitan Area: Arizona State University. 
Daneshvary, R., \& Schwer, K. (2000).The Association endorsement and consumers' intention to Cornan, S., Hess, A., \& Justus, Z. (2006). Credibility in the global war in terrorism: Strategic principles and research agenda. Consortium for Strategic Communication, Phoenix Metropolitan Area: Arizona State University.

Dearstyne, B. W. (2005). Blogs: The new information revolution? Information Management Journal, 39(5), 38-44.

Deuze, M. A., Bruns \& C. Neuberger (2007). 'Preparing for an age of participatory news.'Journalism Practice, 1(3):322-338.)

Eisend, M. (2004). Is it still worth to be credible? A meta-analysis of temporal patterns of source credibility effects in marketing. Advances inConsumer Research, 31, 352-357

Eldridge II, S. A. (2017). The digital journalist: The journalistic field, boundaries, and disquieting change. In Eldridge II, SA, Franklin, B, editors. The Routledge Companion to Digital Journalism Studies. 1st (ed.). New York: Routledge;. pp. 44-54. 9781138887961.ch4

Hovland, C., Janis, I., \& Kelley, H. (1953).Communication and persuasion.New Haven, GT: Yale University Press.

Johnson, T. J., \& Kaye, B. K. (2004). Wag the blog: How reliance on traditional media and the Internet influence credibility perceptions of weblogs among blog users. Journalism \& Mass Communication Quarterly, 81(3), 622-642.

Karlsson, M. \& Clerwall, C. (2019) Cornerstones in Journalism, Journalism Studies, 20:8, 1184-1199, DOI: 10.1080/1461670X.2018.1499436 Accessed on $16^{\text {th }}$ June, 2020 from https://doi.org/10.1080/1461670X.2018.1499436

Kellner, D. (2012). The media and social problems (http://www.gseis.ucla.edu/faculty/kellner/)

Kwak, D. H., Kim, Y. K., \& Zimmerman, M.H. (2010).User- versus mainstream-mediagenerated content: Media source, message valence, and team identification and sportconsumers' response. International Journal of Sport Communication, 2010, 3, $402-421$

Lesica, J.D. (2003). What is participatory journalism.Online Journalism Review August, 7, htt/ww. Ojr/Org/Ojr/workplace // 1060217106. Php.

Luo, Y.\& Harrison, T. M. (2019). How citizen journalists impact the agendas of traditional media and the government policymaking process in China. Global Media and ChinaVol. 4(1) 72-93 sagepub.com/journals-permissions DOI: 10.1177/2059436419835771 journals.sagepub.com/home/gch

Mandalois, R. (2013). RADAR: An approach for helping students evaluate Internet sources. Journal of Information Science 39 (4): 470-478.

Mckees, A. (2003). Textual analysis. A beginner's guide. Thousand Oaks,CA: Sage. 
Miller, C. (2010). Why Twitter's C.E.O. demoted himself. The New York Times. Retrieved fromhttps://www.nytimes.com/2010/10/31/technology/31ev.html accessed on 26th June, 2020.

Murphy, C. J. \& Auter, P. J. (2012). The Politics of the Source: How the credibility of a News Source Changes Based on the Political Perception of Blogs. American Communication Journal, 14 (1): 1-17

Nah, S. \& Chung, D. S). Communicative action and citizen journalism: A case study of OhmyNews in South Korea.International Journal of Communication 10, 2297-2317 1932-8036/20160005

Noor, R. (2017).Citizen journalism vs. mainstream journalism: A study on challenges posed by amateurs.Athens Journal of Mass Media and Communications-Volume 3, Issue 1 Pages 55-76 https://doi.org/10.30958/ajmmc.3.1.4 doi=10.30958/ajmmc.3.1.4

Nwabueze C. D and Ikegbunam, P.C. (2016). Evaluating the ethical content of news photographs in mainstream and social media. Journal of Mass Media Review, Department of Mass Communication Lagos State University. 86-94.

Nwabueze, C. \& Ikegbunam, P., (2015). Source credibility and Internet blog news stories: Implications to securityin Nigeria, ANSU Journal of Arts and Social Sciences, 3 (2): 22-36.

O'Keefe, D. J. (2002).Persuasion: Theory and research (2nd ed.). Beverly Hills: Sage Publications.

Olumuji, E., Asemah, A. S and Edego L. O. (2013).Citizen journalism and credibility. A study of Sahara Reporters, com, ANSU Journal of Art and Social Sciences, (2):1-13.

Porter, L. V., Trammell, K. D. S., Chung, D., \& Kim, E. (2007). Blog power: Examining the effects of practitioner blog use on power in public relations. Public Relations Review,33(1), 92-95.

Reese, S. D. (2016). The new geography of journalismresearch, Digital journalism. 4, (7). Pp. 816-826. Doi:10.1080/21670811.2016.1152903.

Russell, A. (2013). Networked: A contemporary history of news in transition. 1st ed. Cambridge: Polity Press.

Saad, L. (2016, June). Americans' confidence in newspapers at new low. Gallup. Retrievedfrom http://www.gallup.com/poll/192665/americans-confidence-newspapersnew-low.Aspx

Sambrook, R. (2005). “Citizen Journalism and the BBC”, Nieman Reports, Winter 2005

Ude-Akpeh, C. E. \& Ukwella, C. O. (2017).Professionalization of Media Practice in Nigeria: An Analytical Survey.IOSR Journal Of Humanities And Social Science (IOSR-JHSS) Volume 22, Issue 6, Ver. 2 (June. 2017) PP 08-15 e-ISSN: 2279-0837, p-ISSN: 2279 
0845. www.iosrjournals.org DOI: 10.9790/0837-2206020815 www.iosrjournals.org 8 | Page

Umeogu, B. (2012). Source credibility: A philosophical analysis open journal of philosophy 2, (2) pp 112-115. Accessed Online from SciRes (http://www.SciRP.org/journal/ojpp) http://dx.doi.org/10.4236/ojpp.2012.22017 112 26/4/2020

Višňovský, J, Radošinská, J,2017). Online journalism: Current trends and challenges. Accessed from http://dx.doi.org/10.5772/68086

Yamamoto, M \& Nah, S. (2018).A multilevel examination of local newspaper credibility. Journalism \& Mass Communication Quarterly Vol. 95(1) 76- 95 DOI: 10.1177/1077699017721486 http://journals.sagepub.com/home/jmq

Zerfass, A, Verhoeven, P, Moreno, A, Tench, R, Verčič, D. (2016). European Communication Monitor 2016. Exploring Trends in Big Data, Stakeholder Engagement and Strategic Communication. Results of a Survey in 43 Countries. Brussels: EACD/EUPRERA 